\title{
Rancang Bangun Sistem Kontrol Kursi Terapi Bagi Penderita Cerebral Palsy
}

\author{
Muhammad Arsyad $^{1 *}$, Simon Ka'ka ${ }^{2}$, A.Muh.Rahmat ${ }^{3}$, Mustajabah ${ }^{4}$, dan $\operatorname{Irmin}^{5}$ \\ 1,2,3,4,5 Jurusan Teknik Mesin, Politeknik Negeri Ujung Pandang, Makassar 90245, Indonesia \\ *arsyadhabe@poliupg.ac.id
}

\begin{abstract}
The therapy chair for cerebral palsy sufferers is a device designed to help sufferers carry out the therapy process. This tool consists of a control system that makes it easy for sufferers to increase the independence of patients in operating the device. The purpose of this tool is to improve cerebral palsy therapy. This chair uses a hydraulic system as an actuator and an Arduino as a control device. This method is applied, namely designing, manufacturing, assembling and testing. The results of this study indicate that in the experiments that have been conducted, it is found that to adjust the position of the therapy chair until the patient is standing requires the lowest time in patient $A$ is 65 seconds with the patient's body weight is $70 \mathrm{~kg}$ while for the highest time, namely in patient D is 92 seconds with the patient's body weight $73 \mathrm{Kg}$. Based on the results of these tests, it was concluded that the therapy chair with the Arduino Uno control system could make it easier for patients to operate and streamline the time spent in the therapy process
\end{abstract}

Keywords: design; control; chair; palsy

\begin{abstract}
Abstrak: Kursi terapi untuk penderita cerebral palsy merupakan suatu alat yang didesain untuk membantu para penderita melakukan proses terapi . Alat ini terdiri dari sistem kontrol yang memudahkan penderita untuk meningkatkan kemandirian penderita dalam mengoperasikan alat tersebut. Tujuan pembuatan alat ini ialah untuk meningkat terapi cerebral palsy. Pada kursi ini menggunakan sistem hidrolik sebagi aktuator dan arduino sebagai alat kontrol. Metode ini diterapkan yaitu perancangan, pembuatan, perakitan dan uji coba. Hasil penelitian ini menunjukkan pada percobaan yang telah dilakukan diperoleh bahwa untuk mengatur posisi kursi terapi hingga pasiesn berdiri membutuhkan waktu terendah pada pasien A ialah 65 detik dengan berat badan pasien yaitu $70 \mathrm{~kg}$ sedangkan untuk waktu tertinggi yaitu pada pasien D ialah 92 detik dengan berat badan pasien $73 \mathrm{Kg}$. Berdasarkan hasil pengujian tersebut disimpulkan bahwa kursi terapi dengan sistem kontrol arduino uno dapat memudahkan pasien dalam pengoperasiaan dan mengefesiensikan waktu yang digunakan dalam proses terapi.
\end{abstract}

Kata kunci : rancang; kontrol; kursi; palsy

\section{PENDAHULUAN}

Seiring berkembangnya ilmu pengetahuan dan teknologi kesehatan, terciptalah suatu alat kesehatan yang disebut easystand series. Easystand adalah salah satu alat bantu berdiri berupa kursi, dimana fungsinya adalah untuk melatih otot tungkai bagi penderita kelumpuhan guna mencegah kekakuan otot pada tungkai. Penggerak utama dari Easystandseries adalah pompa hidrolik. Sebagai Penderita penyakit cerebral palsy atau kelumpuhan otak besar termasuk cacat fisik, yang mana penderita penyakit ini mengalami kekakuan otak, kelumpuhan dan gangguan fungsi saraf lainnya [1]. Pada penelitian ini akan dirancang kemudian dibuat kursi terapi untuk penderita cerebral palsy dengan menggunakan sistem otomatis. Sementara penggunaan kursi terapi sebelumnya masih menggunakan sistem manual, sehingga menggunakan waktu yang cukup lama dalam proses terapi, yaitu perubahan posisi penderita dari posisi duduk menjadi berdiri. Untuk mennyelesaikan permasalahn tersebut maka perlu dilakukan perencanaan dan pembuatan system penggerak kursi secara otomatis dengan menggunakan system hidraulik. Metode yang digunakan dalam pengontrolan kursi terapi yaitu menggunakan arduino media kontrol yang menggerakan hidraulik sebagai aktuator [2].

Kursi merupakan "tempat duduk yang berkaki dan memiliki sandaran". Definisi penderita adalah "orang yang menderita (kesusahan, sakit, cacat, dan sebagainya)" [3]. Sedangkan definisi cerebral 
palsy adalah "Cerebral palsy lebih tepat dikatakan suatu gejala yang kompleks daripada suatu penyakit yang spesifik $[4,5]$.

\section{METODE PENELITIAN}

A. Tempat dan Waktu Pelaksanaan

Kegiatan ini dilaksanakan Bengkel Mekanik, dan Bengkel Las Jurusan Teknik Mesin Politeknik Negeri Ujung Pandang. selama \pm 7 bulan.

\section{B. Metode Pelaksanaan}

Kegiatan ini dibagi beberapa tahap yaitu:

1. Perancangan

2. Pembuatan

3. Perakitan

Ada beberapa hal yang harus diperhatikan dan dilakukan dalam proses perancangan ini, yaitu:

a. Pembuatan gambar desain yang dibuat beserta dengan dimensinya.

b. Melakukan perhitungan terhadap komponen-komponen alat yang akan dibuat.

c. Menentukan bahan yang digunakan pada tiap komponen.

Komponen standar ini merupakan komponen yang bisa dibeli secara langsung tanpa melalui proses pembuatan. Berikut komponen-komponen standar yang digunakan.

a. Pompa Hidrolik

b. Arduino Uno

c. Adaptor

d. Power Window

e. Driver Motor

Komponen-komponen yang telah dibuat, dan komponen standar yang dibeli kemudian dirakit sehingga membentuk alat yakni, Kursi Penderita Cerebral Palsy Sistem Hidrolik. Adapun langkahlangkah dalam proses perakitan adalah sebagai berikut:

a. Rangka meja dipasang pada rangka utama dengan baut dan mur sebagai pengikat.

b. Hidrolikdipasang pada dudukannya dan dongkrak hidrolik dihubungkan dengan rangka utama.

c. Stand kursi dipasang pada ujung atas dongkrak hidrolik yang dihubungkan dengan baut dan mur.

d. kursi dipasang pada dudukannya menggunakan sambungan poros.

e. sandaran punggung dihubungkan pada stand kursi hingga membentuk mekanisme.

f. Penahan tangan dipasang pada kursi menggunakan sambungan las dan sambungan baut.

g. Pijakan kakidipasang pada rangka utama dengan menggunakan klem $U$ dan mur sebagai pengikat.

h. Stand meja dipasang pada rangka meja dengan baut khusus sebagai pengunci posisi meja. penahan lutut dan penahan dada dipasang pada stand masing-masing dengan skrup, baut dan mur sebagai pengikat.

\section{HASIL DAN PEMBAHASAN}

Tabel 1. Kondisi Sampel Pengujian

\begin{tabular}{|c|c|c|c|}
\hline No & Sampel & Massa Sampel & Kondisi Sampel \\
\hline 1 & A & 55 & Baik \\
\hline 2 & B & 63 & Baik \\
\hline 3 & C & 71 & Baik \\
\hline 4 & D & 73 & Baik \\
\hline 5 & E & 65 & Baik \\
\hline
\end{tabular}


110 Muhammad Arsyad, Simon Ka'ka, A.Muh.Rahmat, Mustajabah, Irmin. Rancang Bangun Sistem Kontrol Kursi Terapi Bagi Penderita Cerebral Palsy

Tabel 2. Hasil Pengujian Kursi Celebral Palsy Otomotis

\begin{tabular}{|c|c|c|c|c|}
\hline No & $\begin{array}{l}\text { Variabel } \\
\text { Pengujian }\end{array}$ & Sampul & $\begin{array}{l}\text { Kemampuan Sampel } \\
\text { mengoperasikan alat }\end{array}$ & $\begin{array}{l}\text { Waktu } \\
\text { (detik) }\end{array}$ \\
\hline \multirow{5}{*}{1} & \multirow{5}{*}{$\begin{array}{l}\text { Mengatur Posisi } \\
\text { Meja }\end{array}$} & A & Mampu & 20 \\
\hline & & B & Mampu & 23 \\
\hline & & $\mathrm{C}$ & Mampu & 22 \\
\hline & & $\mathrm{D}$ & Mampu & 15 \\
\hline & & $E$ & Mampu & 20 \\
\hline \multirow{5}{*}{2} & \multirow{5}{*}{$\begin{array}{l}\text { Mengatur Posisi } \\
\text { Penahan Lutut }\end{array}$} & $\mathrm{A}$ & Mampu & 10 \\
\hline & & $\mathrm{B}$ & Mampu & 15 \\
\hline & & $\mathrm{C}$ & Mampu & 12 \\
\hline & & $\mathrm{D}$ & Mampu & 10 \\
\hline & & $E$ & Mampu & 15 \\
\hline \multirow{5}{*}{3} & \multirow{5}{*}{$\begin{array}{l}\text { Merubah posisi } \\
\text { Kursi (duduk- } \\
\text { berdiri) }\end{array}$} & $\mathrm{A}$ & Mampu & 65 \\
\hline & & $\mathrm{B}$ & Mampu & 75 \\
\hline & & $\mathrm{C}$ & Mampu & 85 \\
\hline & & $\mathrm{D}$ & Mampu & 92 \\
\hline & & $E$ & Mampu & 80 \\
\hline
\end{tabular}

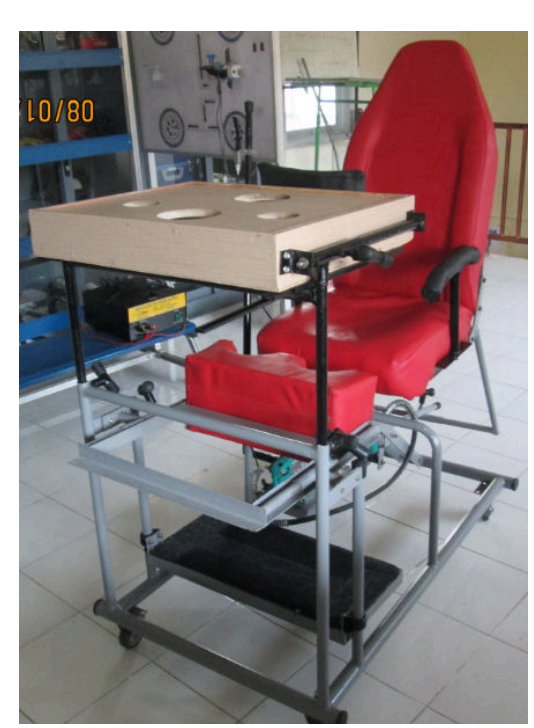

Gambar 1. Kursi Celebral Palsy Sistem Hydrolic [6]

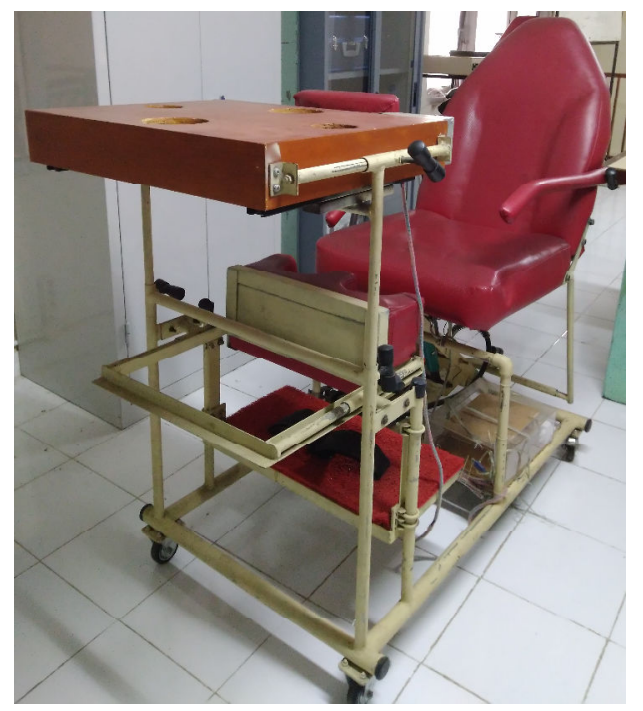

Gambar 2. Kursi Celebral Palsy Sistem Otomatis

Produk yang dihasilkan seperti terlihat pada Gambar 2 yaitu suatu kursi yang mampu merubah posisi penggunanya dari posisi duduk hingga posisi berdiri, dan sebaliknya serta mengatur kecepatan perubahan posisi tersebut. Adapun perbandingan alat ini dengan alat sebelumnya [6,7] yaitu:

1. Penggunaan baut

Untuk memudahkan penderita mengubah posisi meja dalam hal ini naik-turun dan maju-mundur, sambungan meja yang sebelumnya disambung dengan baut tembus diubah menjadi sambungan yang menggunakan baut khusus yang bisa diputar dengan tangan. Hal ini memberikan dampak yang baik bagi kemandirian penderita dalam mengoperasikan alat. Untuk mengaplikasikan baut tersebut pada sambungan meja, besi pipa yang berfungsi sebagai rangka meja dilubangi dan dipasangi mur. Kepala baut yang dibuat khusus memudahkan penderita untuk mengatur posisi 
meja karena untuk mengencangkan atau melonggarkan baut, penderita cukup memutar baut menggunakan tangan.

2. Kursi

Pada bagian kursi ditambahkan tombol otomatis bagi pasien agar dapat mengoperasikan alat secara otomatis dan menyesuaikan kecepatan tergantung kebutuhan terapi. Mekanisme yang digunakan ialah hidraulik sebagai penopang kursi yang telah ditambahkan motor yang berfungsi sebagai aktuator untuk menggerakan pompa hidraulik baik untuk menaikkan dan menurunkan kursi.

Sistem kontrol yang digunakan yaitu Arduino Uno dan driver Motor untuk mengendalikan motor yang berfungsi menaikkan hidraulik.

3. Meja

Meja yang sebelumnya berupa papan tanpa pinggiran diganti dengan meja yang memiliki pinggiran serta memiliki stan khusus yang berfungsi sebagai tempat piring, mangkuk dan gelas sehingga meminimalisir jatuhnya benda tersebut bila diletakkan di atas meja.

4. Sandaran Tangan

Sandaran tangan yang hanya berupa pipa $1 / 2$ inch diubah dengan sandaran tangan khusus yang permukaannya lebih lebar dan rata sehingga tangan tidak rentan terjatuh.

5. Roda

Alat ini juga ditambahkan dengan 4 buah roda pada bagian rangka utama sehingga dapat dipindahkan dengan mudah.

Dengan beberapa perubahan yang dilakukan memungkinkan penderita dapat melakukan aktivitasaktivitas yang tidak dapat dilakukan pada alat sebelumnya seperti makan/minum. Dengan begitu penderita secara tidak langsung memiliki waktu yang lebih banyak dalam mengoperasikan alat, dan diharapkan kondisi penderita bisa segera pulih seiring banyaknya waktu yang digunakan untuk mengoperasikan alat tersebut sebagai proses terapi [6.7].

Berdasarkan tabel 2, diketahui bahwa pada pengujian1 yaitu mengatur posisi meja, sampel A,B,C,D dan $\mathrm{E}$ mampu mengatur posisi meja naik-turun, dan maju-mundur walau sedikit kesulitan pada saat menaikkkan meja..Untuk pengujian 2 yaitu mengatur posisi penahan lutut, sampel A, B, C, D dan E mampu mengatur posisi penahan lutut dengan baik tanpa bantuan orang lain. Begitupun pada pengujian 3 yaitu mengubah posisi kursi, sampel A, B, C, D dan E mampu mengubah posisi dari posisi duduk ke posisi berdiri menggunakan tombol otomatis pada bagian depan meja, dan kembali ke posisi duduk dengan menekan tombol yang juga terpasang pada meja tersebut. Selanjutnya, kelima sampel juga waktu tempuh mengubah kursi dari posisi duduk ke posisi berdiri dipengaruhi oleh berat badan pasien, semakin besar berat badan pasien maka waktu yang dibutuhkan semakin lama begitu pula sebaliknya.

\section{KESIMPULAN}

Modifikasi kursi celebral palsy telah dilakukan dengan sistem otomatis yang menggunakan Arduino Uno dan driver Motor sebagai unit kontrolnya sehingga memudahkan pasien untuk mengubah posisi kursi sesuai yang diinginkan. Kursi untuk Penderita Cerebral Palsy tersebut dapat dioperasikan sendiri oleh penderita tanpa harus dibantu orang lain. Pergerakan pompa hidrolik pada posisi kursi penderita cerebral palsy digerakkan secara sistem otomatis menggunakan arduino uno.

\section{UCAPAN TERIMA KASIH (APABILA ADA)}

Ucapan terima kasih yang tak terhingga kepada Pimpinan Politeknik Negeri Ujung Pandang yang telah memberika kesempatan untuk menggunakan segala fasilitas yang dibutuhkan dalam penyelesaian pembuatan kursi celebral palsy ini. 
112 Muhammad Arsyad, Simon Ka'ka, A.Muh.Rahmat, Mustajabah, Irmin. Rancang Bangun Sistem Kontrol Kursi Terapi Bagi Penderita Cerebral Palsy

\section{DAFTAR PUSTAKA}

[1] Nurcahyo. 2010.Pengertian Cerebral Palsi, (Online), (https://Artikel-kesehatan-/pengertian.cerebral.palsy.html. diakses 21 Desember 2015).

[2] Anggar.2015.Jenis-Jenis Arduino, (online), (http://tentangarduino.blogspot.co.id/2014/09/macam-macam-arduino-iniakansaya.html.diakses 2 januari 2016).

[3] Departemen Pendidikan Nasional. 2002. Kamus Besar Bahasa Indonesia. Jakarta:Balai Pustaka.

[4] Erdina, Leandra.2015 “Cerebral Palsy”.Tugas Presentasi.Makassar:Jurusan Fisioterapi Fakultas Kedokteran Universitas Hasanuddin

[5] Rustyanto,Dwi. 2015.“Data Pasien Klinik Fisioterapi Yayasan Pembinaan Anak Cacat”.Laporan Data Pasien. Makassar: Yayasan Pembinaan Anak Cacat Makassar.

[6] Yasser.,Rifal.,Hairil,. 2015. "Rancang Bangun Kursi Terapi Cerebral Palsy Sistem Hidrolik". Laporan Tugas Akhir. Makassar: Jurusan Teknik Mesin Politeknik Negeri Ujung Pandang.

[7] Sugiswa, Yusuf. 2014. “ Rancang Bangun Kursi Terapi Cerebral Palsy Sistem Hidrolik”. Laporan Tugas Akhir. Makassar: Jurusan Teknik Mesin Politeknik Negeri Ujung Pandang. 